\title{
Note
}

\section{Presence of plasmids in propionic acid bacteria}

\author{
Geneviève PANON \\ I.N.R.A., Laboratoire de Technologie laitière \\ 65, rue de Saint-Brieuc, 35042 Rennes Cedex, France
}

\begin{abstract}
Résumé
Présence de plasmides chez les bactéries propioniques
\end{abstract}

Cinquante-trois souches de bactéries propioniques ont été testées pour la présence de plasmides. Une micro-méthode d'extraction a été appliquée avec succès. Vingt souches possèdent de l'ADN plasmidique. Un de ces plasmides a été purifié en gradient de chlorure de césium après extraction préparative. Son poids moléculaire a été estimé à 4,33 mégadaltons, soit 6,5 Kbases.

\section{Introduction}

Technological performances of lactic acid bacteria routinely used as dairy starter cultures may be improved by genetic modification programme, particularly by genetic transfer system (GASSON, 1984 ; McKAY et al., 1980 ; TSAI and SANDINE, 1987). Desirable characteristics or metabolic properties in lactic streptococci have been shown to be clearly plasmid-related (DAVIES and Gasson, 1981 ; McKay, 1983 ; Orberg and Sandine, 1985). Many published procedures are suitable for rapid screening of plasmids of lactic acid bacteria (Birnboim and Doly, 1979 ; Klaenhammer, 1984 ; Yu et al., 1982 ; Portnoy et al., 1981).

Propionic acid bacteria are routinely used in France in cheese industries, such as Emmental, Beaufort, Gruyère de Comté. Ripening, flavor, and quality of these cheeses are closely related to propionic acid fermentation (HETTINGA et al., 1974) and to growth of these bacteria during cheese maturation (PARK et al., 1967). But in fact, very few informations are available concerning the metabolic, proteolytic, lipolytic activities and the genetic potential of these bacteria.

In this paper we show the existence of extrachromosomal and covalentlyclosed-circular (CCC) DNA molecules. 


\section{Materials and method}

\section{A. Origin and maintenance of cultures}

Twenty eight strains originated from Centre National de Recherches Zootechniques, C.N.R.Z., 78350 Jouy-en-Josas, France. Twenty five other strains were kindly provided by cheese making industries and private firms. All cultures were grown in Yeast Extract Lactate (Y.E.L.) broth according to Peberdy and Fryer (1976).

\section{B. Plasmid DNA isolation}

A rapid small-scale plasmid DNA screening described (PorTnoy et al., 1981) has been used. For large scale plasmid isolation, one strain of Propionibacterium acidi-propionici was selected. Plasmid extraction protocole was based on large scale procedure (PORTNOY et al., 1981). Plasmid-enriched fraction was purified in a CsCl-ethidium bromide density gradient (MANIATIS et al., 1982).

\section{Digestion with restriction enzymes}

Following enzymes (Boehringer-Mannheim) were tested : Eco RI, Hind III, Cla I, Ava I, Sau 3A, Bam HI, Sac I. Respective buffers and optimum temperatures were used according to recommandations of supplier. Lambda DNA Hind III was used as reference.

\section{Agarose gel electrophoresis}

We did horizontal electrophoresis. Protocole has been developed (Meyers et al., 1976). Agarose gel electrophoresis $(0.5 \%)$ was performed in Tris-Borate EDTA (TBE) buffer, containing $90 \mathrm{mM}$ Tris ( $\mathrm{pH} 8.0$ ), $90 \mathrm{mM}$ borate, $1 \mathrm{mM}$ EDTA. Gels $(14 \mathrm{~cm})$ were run at 80 volts for $6 \mathrm{~h}$ (screening) or 100 volts for $3 \mathrm{~h}$ (restriction enzymes digestion). They were stained for $10 \mathrm{~min}$ in water containing $2.5 \mu \mathrm{g} / \mathrm{ml}$ of ethidium bromide, then destained in water for the same period. Plasmid DNA bands were observed after exposing the destained gel to UV transilluminator (model C 63) and recorded by Polaroid MP3 apparatus photography with Polaroid film 667.

\section{Results and discussion}

After small scale rapid screening of plasmids, twenty strains revealed presence of 1,2 , or multiple plasmid DNA bands (fig. 1 and fig. 2). Three different patterns could be seen : sixteen strains belong to the first one, three to the second, and one to the third one (fig. 3). Plasmid profile of Propionibacterium acidi-propionici was consistent with CsCl-Et-Br purified samples. Plasmid DNA purification was tested by digestion with restriction enzymes (fig. 4). It can be seen that the digestion is complete with all enzymes, except 


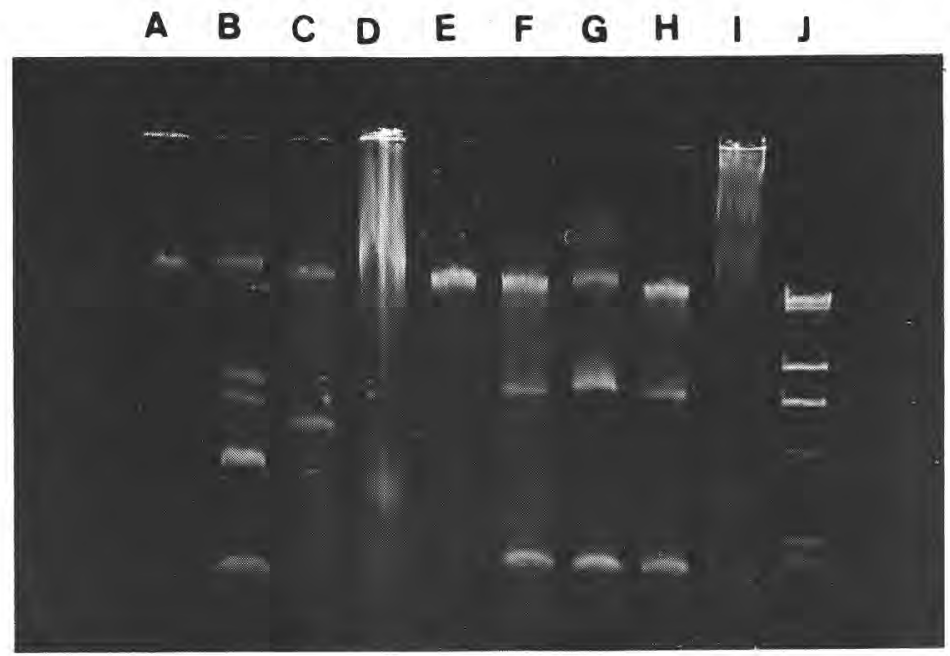

Fig. 1

Agarose gel electrophoresis of plasmid DNA from propionic acid bacteria strains, after small scale procedure extraction; $A$ : P. acidi-propionici ; $B$ : P. freud. freudenreichii $1 ; C$ : P. thoenii ; $D$ : P. freud. freudenreichii $2 ; E$ to $I$ : different strains of $\mathrm{P}$. freud. shermani; $J$ : lambda DNA Hind III.

Electrophorèse en gel d'agarose de l'ADN plasmidique de bactéries propioniques après micro-extraction; $A$ : P. acidi-propionici ; $B$ : P. freud. freudenreichii $1 ; C$ : P. thoenii ; $D$ : P. freud. freudenreichii $2 ; E \grave{a} I$ : différentes souches de P. freud. shermani ; $J$ : ADN du phage lambda digéré par l'enzyme de restriction Hind III.

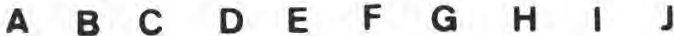



Fig. 2

Agarose gel electrophoresis of plasmid DNA from propionic acid bacteria strains, after small scale procedure extraction ; $A$ : lambda DNA Hind III ; $B$ : P. granulosum ; $C$ : P. thoenii ; $D:$ P. jensenii ; $E$ : P. acidi-propionici $I ; F:$ P. acidi-propionici $2 ; G$ to I: different strains of $\mathrm{P}$. freud. shermani ; $J$ : lambda DNA Hind III.

Electrophorèse en gel d'agarose de l'ADN plasmidique de bactéries propioniques après micro-extraction ; $A$ : $A D N$ du phage lambda digéré par l'enzyme de restriction Hind $I I I ; B$ : P. granulosum ; $C: \mathrm{P}$. thoenii ; $D: \mathrm{P}$. jensenii ; $E: \mathrm{P}$. acidi-propionici $1 ; F:$ $\mathrm{P}$. acidi-propionici $2 ; G$ à $I$ : différentes souches de P. freud. shermani ; $J: A D N d u$ phage lambda digéré par l'enzyme de restriction Hind III. 


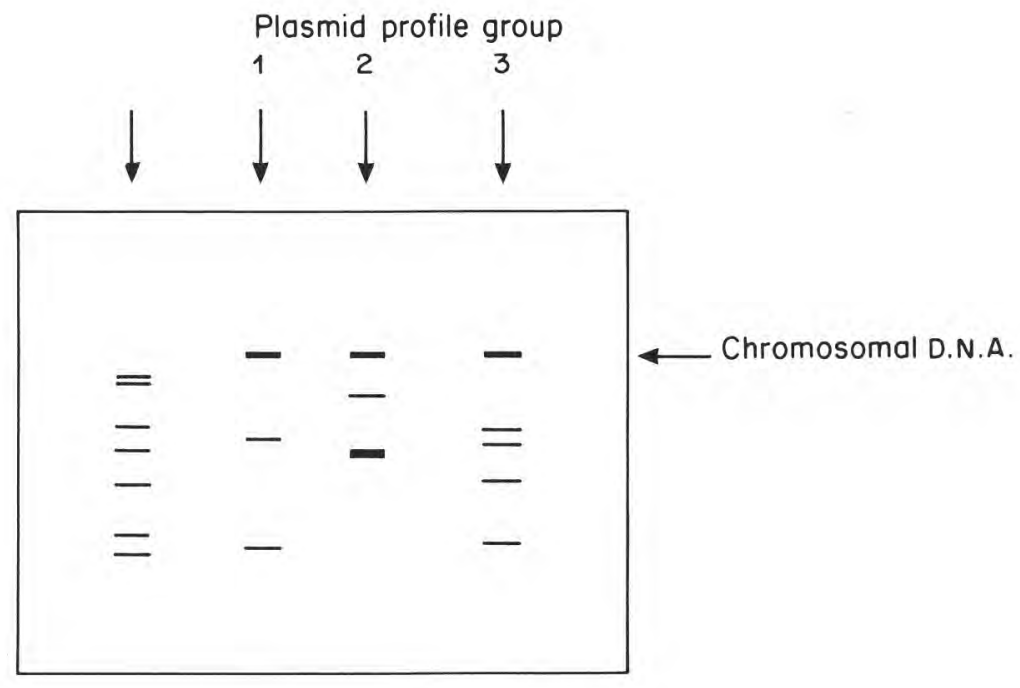

Fig. 3

Schematic plasmid profiles from propionic acid bacteria; from left to right: Lambda DNA Hind III ; group 1 plasmids; group 2 plasmids; group 3 plasmids.

Représentation schématique des profils plasmidiques observés chez les bactéries propioniques; de gauche à droite : ADN du phage lambda digéré par l'enzyme de restriction Hind III ; profil de type 1 ; profil de type 2 ; profil de type 3.

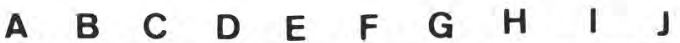

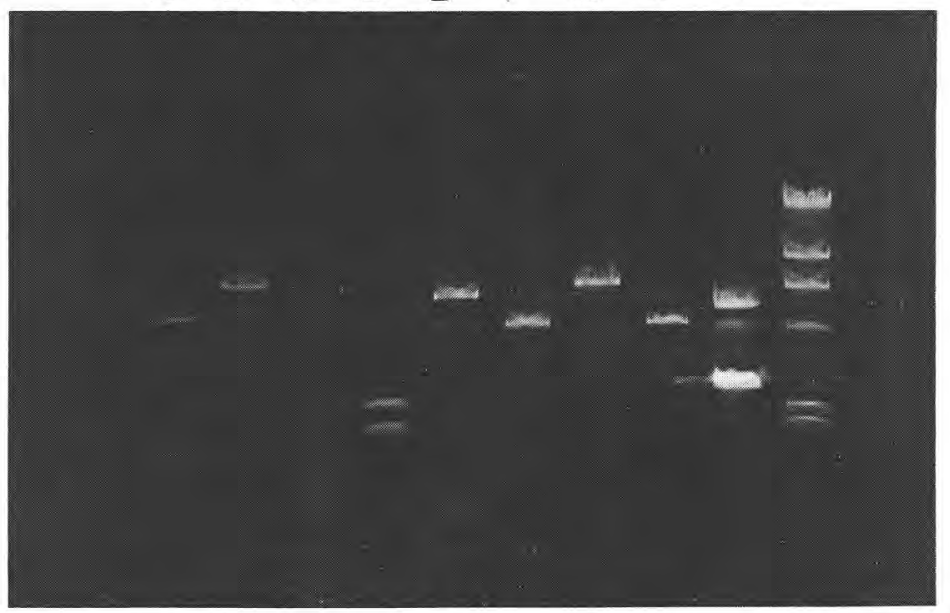

Fig. 4

Plasmid from $\mathrm{P}$. acidi-propionici strain purified by $\mathrm{Cs} \mathrm{Cl}-\mathrm{Et}-\mathrm{Br}$ was treated by restriction enzymes; $A$ : Sac I; B : BamHI; C:Sau 3A ; D : Ava I; E : Cla I; F : Hind III ; $G$ : EcoRI; H : control, no treatment; I: pBR322 ; J : Lambda DNA Hind III.

Traitement par les enzymes de restriction de l'ADN plasmidique extrait d'une souche $\mathrm{P}$. acidi-propionici après purification en chlorure de césium : $A$ : Sac $I ; B: B a m H I ; C$ : Sau 3A; D: Ava I; E: Cla I; F: Hind III; G: EcoRI; H: témoin, sans traitement; I : plasmide pBR322; J:ADN du phage lambda digéré par l'enzyme de restriction Hind III. 
with Hind III (F). The absence of partial cleavage suggests that plasmid preparation was pure. Molecular weight of this plasmid has been evaluated to $4.33 \times 10^{6}$ daltons, equivalent to $6.5 \mathrm{~Kb}$, after Eco RI digestion, when compared to lambda DNA digested by Hind III (J).

Presence of plasmid DNA in propionic acid bacteria has been described in this study. Plasmids have to be analysed further. We have to see if plasmidencoded genes have any interest in dairy cheese industries. First results suggest that strains obtained from cheese making industries and private firms are closely related.

\section{Acknowledgements}

The author is very grateful to all cheese making industries and private firms for kindly providing Propionic acid bacteria strains tested in the present study.

\section{References}

Birnboim H.C., Doly J., 1979. A rapid alkaline extraction procedure for screening recombinant plasmid DNA. Nucleic Acids Res., 7, 1513-1523.

DAvies F.L., Gasson M.J., 1981. Reviews of the progress of dairy science : genetics of lactic acid bacteria. J. Dairy Sci., 48, 363-376.

Gasson M.J., 1984. Transfer of sucrose fermenting ability, nisin resistance and nisin production into Streptococcus lactis 712. FEMS Microbiol. Lett., 21, 7-10.

Hettinga D.G., Reinbold G.W., Vedamuthu E.R., 1974. Split defect of swiss cheese. 1. Effect of strain of Propionibacterium and wrapping material. J. Milk Food Technol., 37. 322-328.

Klaenhammer T.R., 1984. A general method for plasmid isolation in Lactobacilli. Curr. Microbiol., 10, 23-28.

MCKaY L.L., BaLdWiN K.A., WaLSh P.M., 1980. Conjugal transfer of genetic information in group N Streptócocci. Appl. Environ. Microbiol., 40, 84-91.

McKay L.L., 1983. Functional properties of plasmids in lactic streptococci. Antonie Van Leeuwenhoek, J. Microbiol. Serol., 49, 259-274.

Maniatis T., Fritsch E.F., Sambrook J., 1982. Molecular cloning : a laboratory manual. Cold Spring Harbor Laboratory. Cold Spring Harbor, N.Y.

Meyers J.A., Sanchez D., Elwell L.P., Falkow S., 1976. Simple agarose gel electrophoresis method for the identification and characterization of plasmid deoxyribonucleic acid. $J$. Bacteriol., 127, (3), 1529-1537.

Orberg P.K., Sandine W.E., 1985. Plasmid linkage of proteinase and lactose fermentation in Sireplococcus lactis NCDO 1404. J. Dairy Sci., 68, 572-580.

Park H.S., Reinbold G.W., Hammond E.G., Clark W.S. Jr., 1967. Growth of propionibacteria at low temperature. J. Dairy Sci., 50, 589-591.

Peberdy M.F., Fryer T.F., 1976. Improved selective media for the enumeration of propionibacteria from cheese. N.Z.J. Dairy Sci. Technol., 11, 10-15.

Portnoy A., Moseley S.L., Falkow S., 1981. Characterization of plasmids and plasmid associated determinants of Yersinia enterocolitica pathogenesis. Infect. Immun., 31, 775-782.

TSAI H.J., SANDINE W.E., 1987. Conjugal transfer of nisin plasmid genes from Streplococcus lactis 7962 is Leuconostoc dextranicum 181. Appl. Environ. Microbiol., 53 (2), 352-357.

Yu R.S.T., Hung T.U., AzAD A.A., 1982. Rapid screening of highly purified plasmids in lactic streptococci. Aust. J, Dairy Technol,, 37, 99-103. 